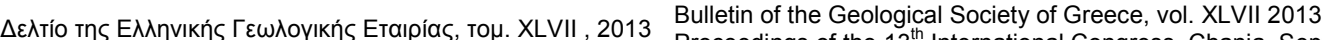

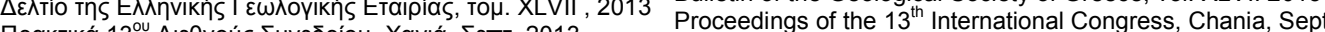

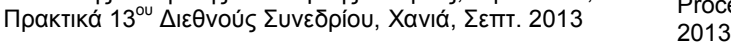

\title{
GROUNDWATER QUALITY CHARACTERISTICS OF THE
} ANAVISOS BASIN

\author{
Angelakopoulou E. ${ }^{1}$, Koumantakis $\mathbf{I}^{2}$, Vasileiou E. ${ }^{2}$ and Stathopoulos N. ${ }^{2}$ \\ ${ }^{1}$ Msc Agriculturist, Amedaiou Han 1, 11525, Athens, Greece,eva_angelak@yahoo.gr \\ ${ }^{2}$ National Technical University of Athens, School of Mining \& Metallurgical Engineering, \\ Laboratory of Engineering Geology \& Hydrogeology, Heroon Polytechniou 9, 15780, Athens, \\ Greece.,koumantakisioannis@gmail.comelvas@metal.ntua.gr,nstath@metal.ntua.gr
}

\begin{abstract}
The Anavisos basin is located in the southern part of Attica and it is a part of the coastline in the Saronikos Bay. The basin covers an area about 110,91 km². The water needs for potable uses of the area are covered by EYDAP and irrigational needs by private drillings and wells. The salinization of the groundwater and the degradation of the water quality had also been observed in the past in the study area. In this research, the most recent chemical analysis showed that the salinity appears extended in the coastal zone as it was in previous decade. The salinization has proceeded into the inland, so the groundwater is characterized as saline and improper for any use in some cases. The main cause for the sea intrusion is the over-pumping exploitation of the coastline aquifers. The rational developments of the area, the lack of a sewerage system, are the main reasons for the degradation of the groundwater in the basin. Additionally there is not a wastewater treatment system in the area, for reusing these waters.
\end{abstract}

Key words: Anavisos basin, groundwater, Saronikos, salinization.

\section{Пєрі́ $\eta \psi \eta$}

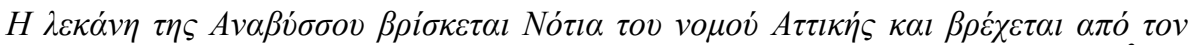

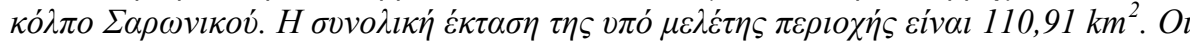

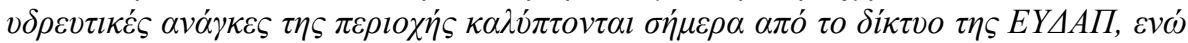

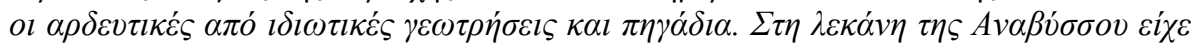

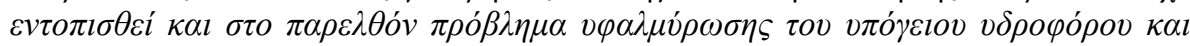

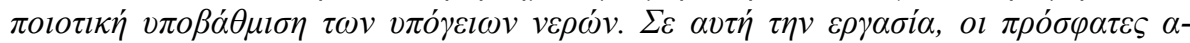

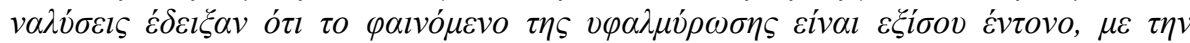

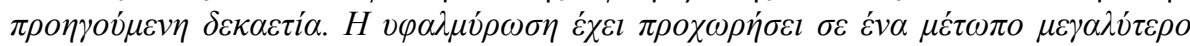

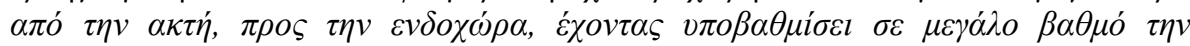

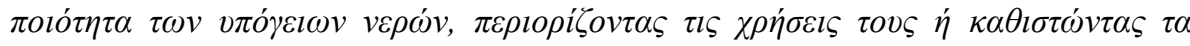

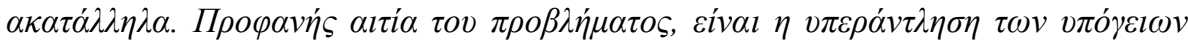

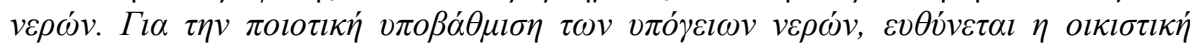

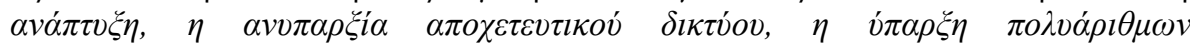

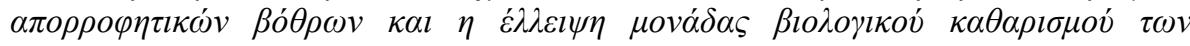
$\lambda v \mu \alpha \dot{\tau} \omega v$.

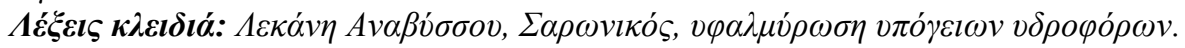

XLVII, No 2-682 


\section{Introduction}

The Anavisos basin is located in the southern part of Attica, the south and west part of it, is wetted by the Saronikos Bay (Figure 1). The research area includes mostly the part of Saronikos municipality; the main villages in the basin are Anavisos and Palea Fokea. The total area is 110, 91 $\mathrm{km}^{2}$. The average altitude of the area is about $100 \mathrm{~m}$ (Pavlopoulos, 1997). Potable water needs of the area are currently covered by EYDAP and the irrigational ones by private drillings and wells.

The aim of this paper was to investigate the water quality in Anavisos basin, to compare this during the time 2001-2011 and to suggest a rational water management.

In the Anavisos basin, salinization and degradation of the groundwater quality had also been observed in the past. The saline front has moved further into the inland and has degraded significantly the ground's water quality, restricting or prohibiting the use of it.

The increase water demands have been caused by the constant residential development of the area, in combination with the population growth and the intense agricultural activities in the area. The touristic development in the area also influences the rational water management. The main reason for the deterioration of water quality is the intense farming due to the overuse of fertilizers, the unrefined residential wastewater, the dumps, the intrusion of the sea water and the two cemeteries, those of Anavisos and Palea Fokea.

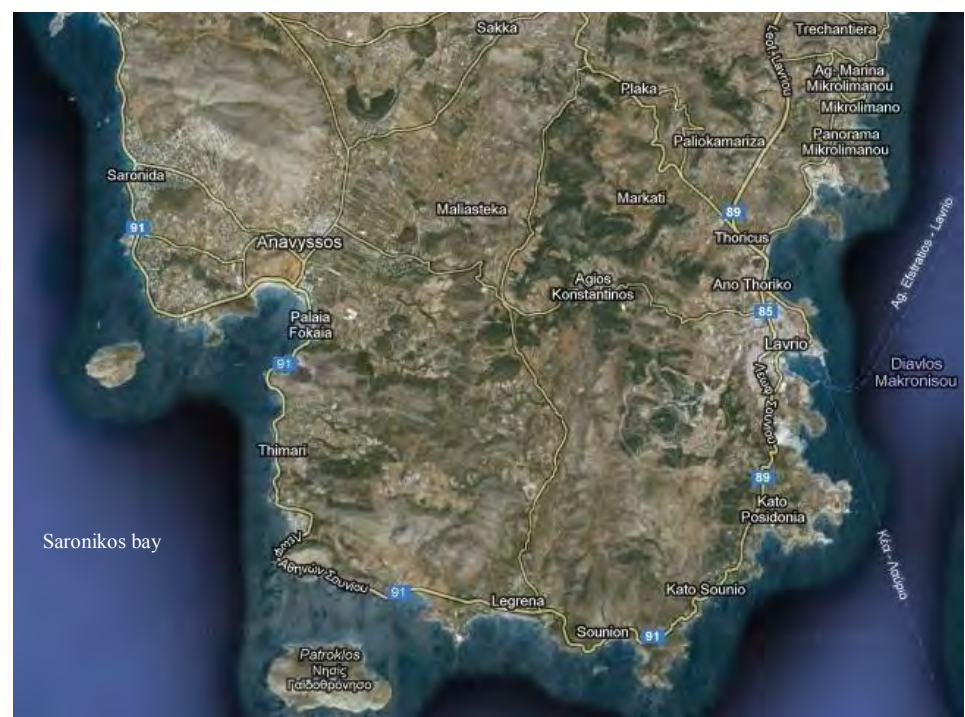

Figure 1 - Geographic position of the studying area (www.googlemap.com).

\section{Geology}

The southern part of Attica presents a complex of geotectonic structure. The southeastern Attica belongs to the Pelagonian zone. Especially the preneogene formations that are developed in the area are metamorphic and semi-metamorphic formations which are marbles, dolomitic marbles, micas schist and phyllites (Pavlopoulos, 1997)

The main part of the study area is covered by Quaternary deposits. These deposits are mainly recent deposits, older and recent fluvial deposits. Karst marbles are often found in the area, especially in the hills and the mountainous zones. Neogene sediments mainly dominate in the western part of the area. These geological formations are consisted of conglomerates, marls, sandstones, sands and clays. Karstified marbles are located in several parts of the area, especially in the southern part. 


\section{Hydrogeology}

In the study area, are developed high permeable (marbles) permeable (conglomerates), impermeable (schists, ophiolite-very low permeability and clays, marls, lacustrine low permeability) and semi-permeable formations (fine grained and fluvial deposits) (Figure 2).

In the Neogene sediments a significant aquifer system is developed southern of Palea Fokea. This aquifer has hydraulic connection with the karstic formations of Gerakina and Asfakeris and lateral recharge from the marbles of Olympos. The alluvial deposits in the mountain ridge, have small thickness and poor recharge, because of the limited run off. In Quaternary deposits there is also an aquifer system of high capacity, which is consisted of shallow unconfined aquifers and deeper confined ones, mainly in the lowland area. In the carbonate formations of Anavisos is developed a karstic aquifer in the north part of the study area.

The main recharge of the aquifers comes from the infiltration of the precipitation, via the percolation from riverbeds and the surface run off in the impermeable formations. The alluvial deposits are in hydraulic contact by the sea because of this, sea intrusion takes place during the period of overexploitation of the coastal aquifers. The marbles don't have any connection with these sediments. These marbles are isolated from impermeable and semi-permeable rocks, which protect the aquifer from sea intrusion. On the contrary the hill of Asfakeris ends to the sea (Mposinakou, 2002).

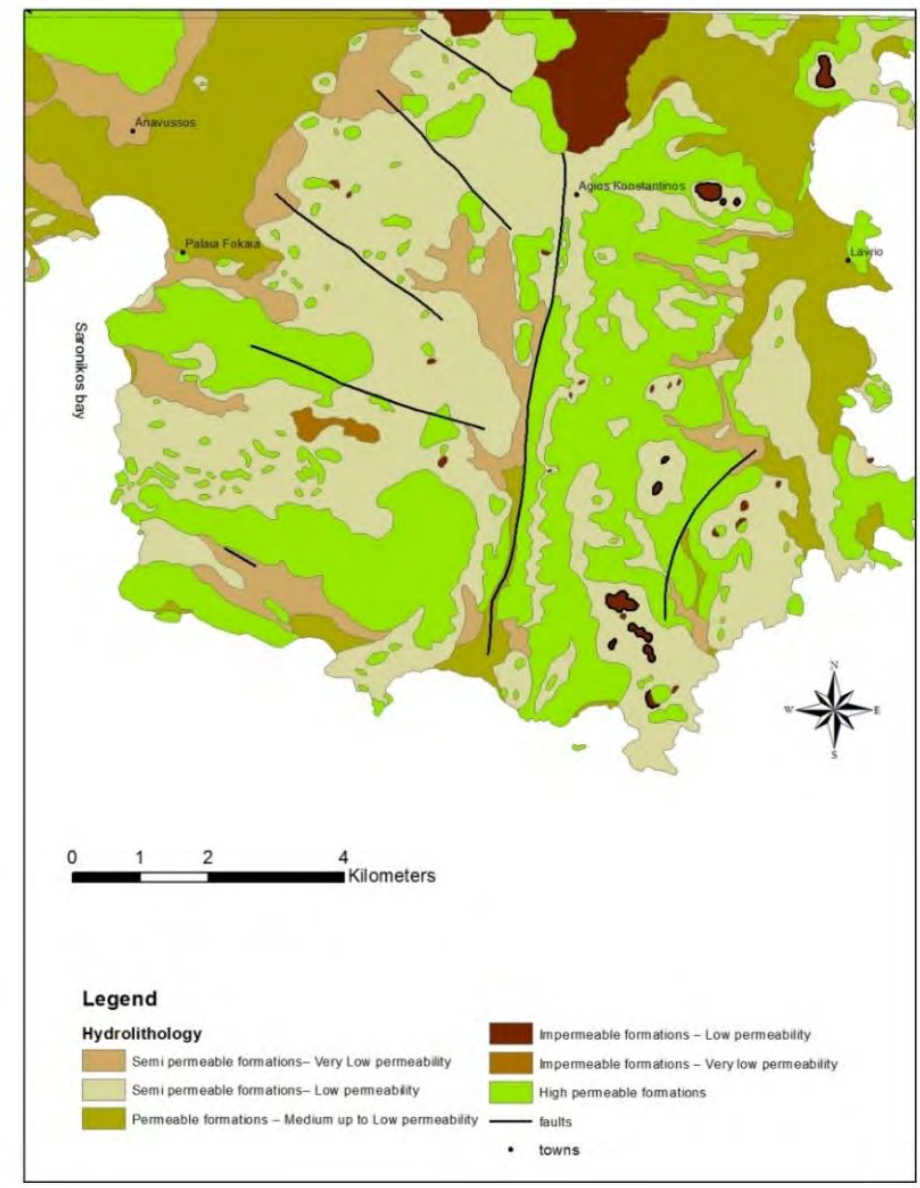

Figure 2 - Hydrogeological map of Anavisos basin.

XLVII, No 2-684 


\section{Meteorological Data}

The climate of Anavisos basin is Mediterranean, mostly the rainfalls are observed during the cold season, as in the summer there are many drought periods. Meteorological data from the Helenic National Meteorological Service, were evaluated from the three nearest stations in the study area: Elliniko (in the period 1955-2004), Markopoulo (time period 1971-2009) and Spata (time period 1974-2004).

The average annual rainfall was estimated at about $403,9 \mathrm{~mm}$, which is considered as law value. During the period from May to September the average monthly rainfall is lower than $20 \mathrm{~mm}$ and as a result there isn't recharge to the aquifers. The average annual temperature is $17,4^{\circ} \mathrm{C}$. The average annual real evapotranspiration was calculated at $305,88 \mathrm{~mm}(76 \%)$ by Thornthwhaite method. Lack of water is observed from April to October, whereas replenishment of soil humidity is taking place in November. Recharge is observed during the period from December until March (figure 3). The diagram of climatic water balance by Thornthwhaite method is described.

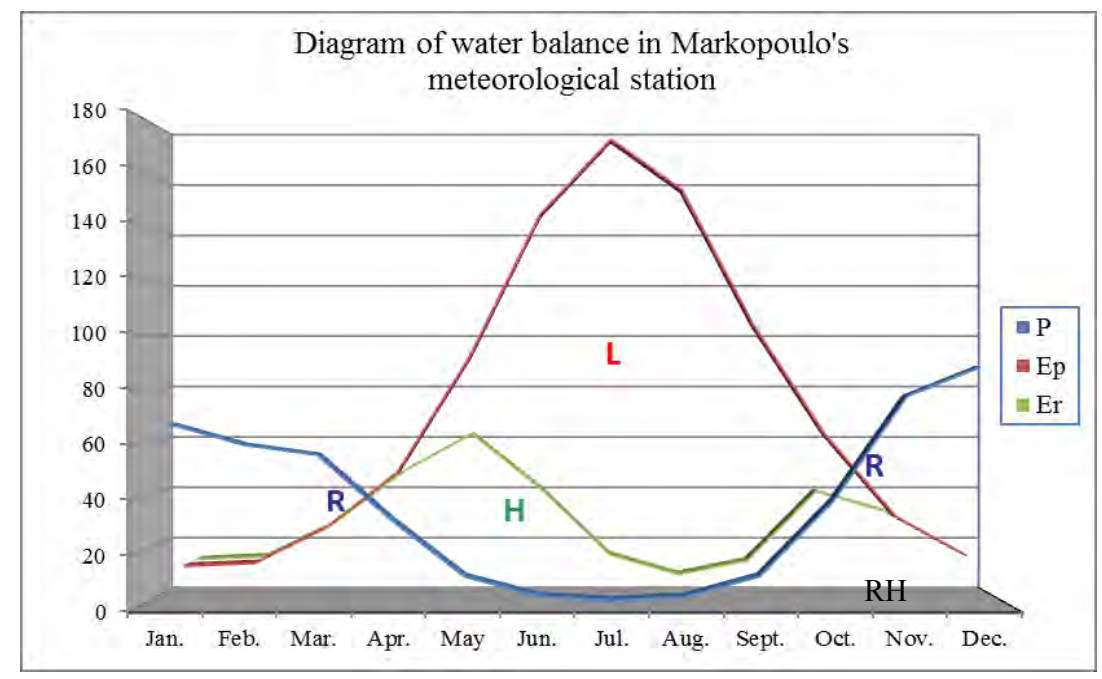

Figure 3 - Water balance in Markopoulo's station according to Thornthwaite, R: Surplus of Water, H: Use of soil humidity, L: Lack of water, RH: Replenishment of soil humidity.

\section{Hydrochemistry}

Several samplings were taken in two different periods (February-March and August 2011) from seventeen drills and wells of the study area. Physical parameters were measured in situ ( $\mathrm{pH}, \mathrm{EC}$, Tem, D.O) and the chemical analyses of major anions and cations were done in the Laboratory of Engineering Geology \& Hydrogeology, in the School of Mining and Metallurgy Engineering. The results of those measurements from the sampling period of August were compared with the previous sampling from Mposinakou (2001), for the same period. The statistical analysis of them is presented to the Table 1 .

High average values of EC, (over $2000 \mu \mathrm{S} / \mathrm{cm}$ ), were estimated for both years 2001 and 2011. The high values of EC were measured in a distance of almost $5,4 \mathrm{~km}$ from the coastline (Figure 4). The spatial distribution of chloride concentration is similar to the one of the EC. The correlation between these parameters is proved by the following diagram for the measurements of the year 2011 (Figure 5).

High average concentration of $\mathrm{Cl}$ (over $300 \mathrm{mg} / \mathrm{l}$ ) are appeared to a distance about 2,1 $\mathrm{km}$ from coastline, for the year 2001 (Bosinakou, 2001). The high concentration of chloride in groundwater must be correlated to the high value of E.C, as a result of the sea intrusion.

XLVII, No $2-685$ 
Table 1 - Statistical analysis of sampling in the year of 2001 and 2011.

\begin{tabular}{ccccccc}
\hline Chemical Elements & \multicolumn{3}{c}{ 2001 (30 samples) } & \multicolumn{3}{c}{ 2011(17 samples) } \\
\hline & Min & Max & Average & Min & Max & Average \\
\hline $\mathbf{E C ~}(\boldsymbol{\mu S} / \mathbf{c m})$ & 412,00 & 8410,00 & 2571,21 & 334,00 & 7860,00 & 2242,48 \\
$\mathbf{C l}(\mathbf{m g} / \mathbf{l})$ & 19,00 & 2368,00 & 497,36 & 9,00 & 2221,00 & 372,47 \\
$\mathbf{N O}_{\mathbf{3}}(\mathbf{m g} / \mathbf{l})$ & 4,50 & 208,00 & 84,47 & 5,00 & 118,00 & 49,64 \\
$\mathbf{N a}^{+}(\mathbf{m g} / \mathbf{l})$ & 12,00 & 860,00 & 234,89 & 34,33 & 650,21 & 220,37 \\
$\mathbf{C a}^{+\mathbf{2}}(\mathbf{m g} / \mathbf{l})$ & 44,05 & 403,68 & 161,65 & 52,46 & 220,26 & 133,64 \\
$\mathbf{M g}^{+\mathbf{2}}(\mathbf{m g} / \mathbf{l})$ & 17,50 & 332,42 & 86,09 & 5,19 & 228,18 & 72,83 \\
$\mathbf{H C O}_{3}^{-}(\mathbf{m g} / \mathbf{l})$ & 168,36 & 445,30 & 345,23 & 143,68 & 672,22 & 417,66 \\
$\mathbf{S O}_{4}^{-2}(\mathbf{m g} / \mathbf{l})$ & 32,00 & 440,00 & 219,60 & 33,00 & 450,00 & 209,65 \\
\hline
\end{tabular}

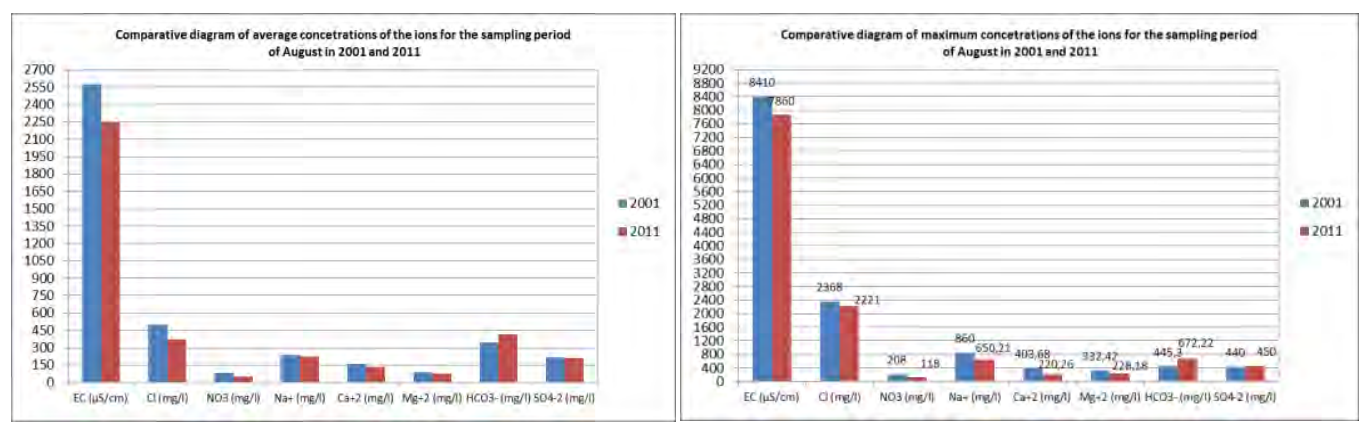

Figure 4 - Statistical diagrams of chemical elements for the years 2001 and 2011.

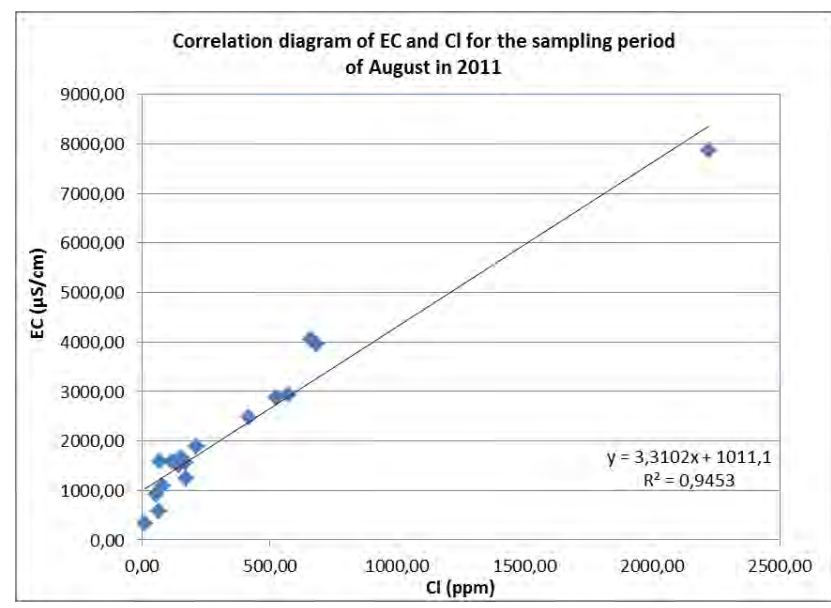

Figure 5 - Correlation diagram of EC and Cl for the time period of August in 2011.

The high concentration of nitrates in the area, is combined with the intense agricultural activity that is occurred in the area, the use of fertilizers and the numerous of non absorbent sinks that exist in the area. Other sources of pollution for nitrate could be considered the two cemeteries, which are located the near the villages of Anavisos and Palea Fokea. Angelakopoulou (2011)

The classification of the water samples, according to the hydrochemical diagrams of Durov, Piper,Wilcox, Schoeller, are mentioned for the year 2011, (Table 2). The hydrochemical diagrams of Piper, Wilcox, Schoeller are presented below (Figure 6). 
As it is obvious, from the table 1 and figure 4, the water quality in 2011 is improved compared to the time period of 2001. All the average concentrations of ions and E.C, in 2011 are lower than the ones of 2001. The common time period for both sampling is on August, the low season for the water table, due to the dry summer. During this decade from 2001 up to 2011 , the rainfall was increased significantly. In the time period of 1999 until 2001, the rainfall in this basin was very low (247 -346 mm, respectively for each year), on the contrary after the year of 2002, there were "rich" recharge from the precipitation to the groundwater, as it was almost doubled (525 mm the average rainfall from 2002 until 2010). This can justify the little change in water quality. In 2001, there was not significant recharge, the extended dry season caused overexploitation of the coastal aquifers and the sea intrusion. In the next years, there was recharge to the aquifers with "fresh"
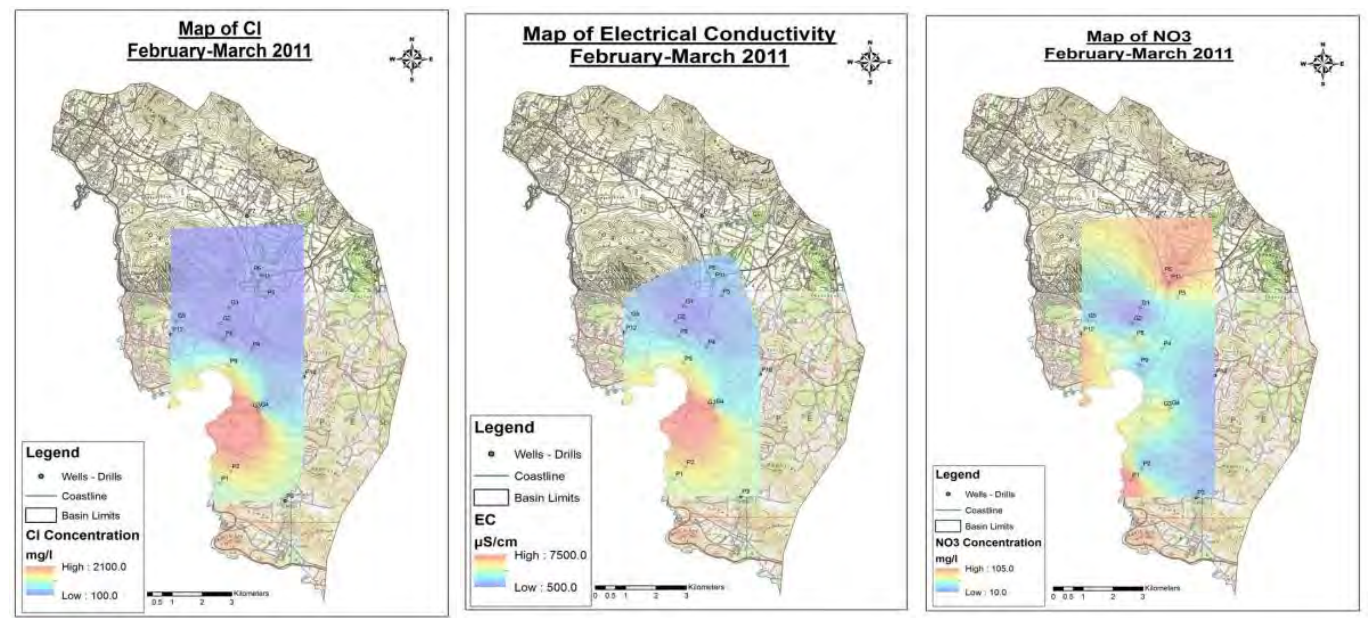

Figure 6 - Distribution Maps of a) E.C. b) $\mathrm{Cl}^{-}$c) $\mathrm{NO}_{3}{ }^{-}$for the period of February-March 2011.

Table 2 - Classification of groundwater according to Durov, Piper, Wilcox, Schoeller diagrams, for the year 2011.

\begin{tabular}{|c|c|c|}
\hline & February-Mars 2011 & August 2011 \\
\hline Durov & \multicolumn{2}{|c|}{ - 5th field (simple water mixing) for the majority of water samples. } \\
\hline \multirow{3}{*}{ Piper } & \multicolumn{2}{|c|}{$\begin{array}{l}\text { - Calcium-magnesium water for the majority of water samples. Calcium-magnesium chloride-sulfate } \\
\text { waters dominate and calcium-magnesium carbonate waters follow. }\end{array}$} \\
\hline & \multicolumn{2}{|c|}{ - Regarding the cations' concentration: Mixed type water for the majority of water samples. } \\
\hline & \multicolumn{2}{|c|}{$\begin{array}{l}\text { - Regarding the anions' concentration: Mixed type water for the majority of water samples, carbonate } \\
\text { waters and chloride waters follow respectively. }\end{array}$} \\
\hline Wilcox & $\begin{array}{l}\text { - C3-S1 category for the majority of water } \\
\text { samples (moderate water quality, appropriate } \\
\text { for the use of irrigation under restrictions). } \\
\text { Exceptions: } \\
\text { - G1 and G2 water samples, C2-S1 category } \\
\text { (good to moderate water quality). } \\
\text { - P10 water sample, C4-S1 category (moderate } \\
\text { to bad water quality). } \\
\text { - P1, P3, P9 water samples, C4-S2\&S3 (bad } \\
\text { water quality). }\end{array}$ & $\begin{array}{l}\text { - C3-S1 category for the majority of water sam- } \\
\text { ples (moderate water quality, appropriate for the } \\
\text { use of irrigation under restrictions). } \\
\text { Exceptions: } \\
\text { - G1 and G2 are moving to C3-S1 category } \\
\text { (moderate water quality). } \\
\text { - P5 and G4 water samples, C2-S1 category } \\
\text { (good to moderate water quality). } \\
\text { - P10 water sample, C4-S1 category (moderate to } \\
\text { bad water quality). } \\
\text { - P3, P8, P9, P10 water samples, C4-S2 (bad } \\
\text { water quality). }\end{array}$ \\
\hline Schoeller & \multicolumn{2}{|c|}{$\begin{array}{l}\text { - Saline water is dominated in the south and in the central part of the basin. } \\
\text { - The coastal aquifers of Anavisos and Palea Fokea are also saline } \\
\text { - Fresh water in the South and East part of the basin, at the Olympos' mountain. Fresh water in G4 } \\
\text { (Palea Fokea), whereas the water from G3 characterized as saline. }\end{array}$} \\
\hline
\end{tabular}


water from the rainfall and it helped a little to decrease the extreme high concentrations, but not at an acceptable level. The sea intrusion is extended in the coastal zone. It is similar the results from the measurements for the wet season (February and March, figure 6). The values of E.C and chloride are very high in the coastal zone, without significant changes to the respective measurements of August.

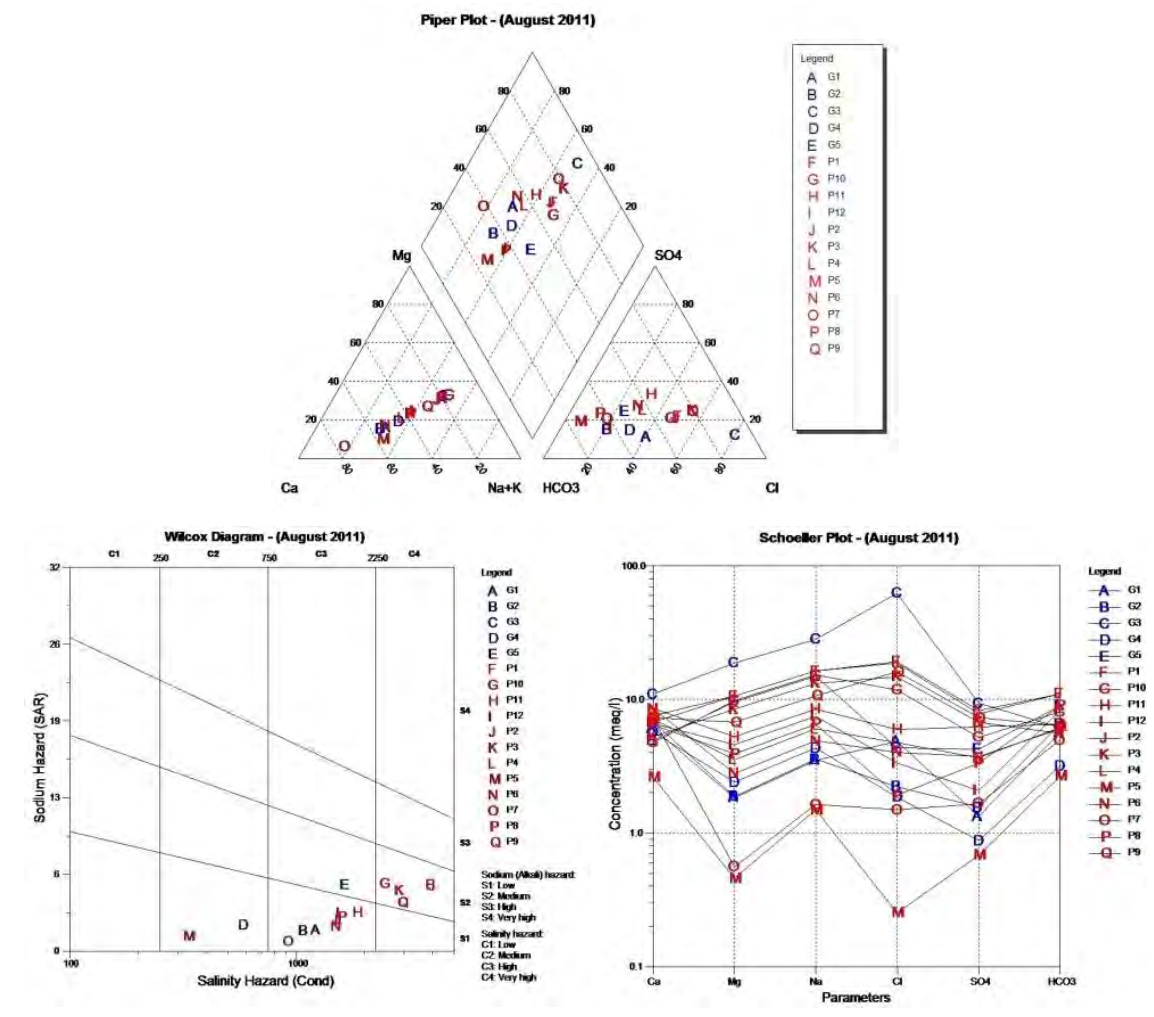

Figure 7 - Hydrochemical diagrams of Piper, Wilcox, Schoeller.

\section{Water Economy}

Regarding the water quality, none of the samples was proper for potable use, apart from those of G1 and G2 drills in the Olympo's marbles, which are of good quality and the one from G5 as well.

The water samples were also classified according to their use for irrigation. The classification was based on the following factors that indicate irrigation water quality: Salinity, which was estimated by measuring the electrical conductivity, infiltration, which was estimated by measuring Sodium Adsorption Ratio (S.A.R.), and the ions of $\mathrm{Cl}, \mathrm{Na}$ and $\mathrm{HCO}_{3}$. According to this classification, two out of seventeen water samples, P5 and P7 (in the central and north part of the basin respectively) are suitable for irrigating the most cultivation. Ten out of seventeen samples are suitable for irrigating resistant cultivations (such as barley, wheat, zucchini, olive, pomegranate, palm, fig, peanut, clover, cucumber, tomato, melon, asparagus). The samples P1, P2, P3 (in the south part of the basin) and P9 (in the Anavisos village) are suitable only for irrigational use in some very resistant to salinity cultivations (such as barley, wheat, zucchini). Finally, one sample, G3 (in the Palea Fokea, village) is completely improper for irrigation. (Misopolinos, 1991; Tsakiris, 2004)

After examining the cultivations of Anavisos and Palea Fokea for 2010, the dominating cultivations are wheat and vineyards, which are mainly not irrigated, diverse vegetables, citrus and nuts, almonds, peanuts which are irrigated and olive trees. A large area is also covered by urban green. Totally, in the Palea Fokea village $2.316 .000 \mathrm{~m}^{2}$ are disposed to agricultural use (including 10.000 
$\mathrm{m} 2$ of urban green), $431.000 \mathrm{~m} 2$ of which are irrigated. In the Anavisos village, $3.625 .000 \mathrm{~m}^{2}$ are disposed to agricultural use (including $35.000 \mathrm{~m}^{2}$ of urban green), $2.613 .000 \mathrm{~m} 2$ of which are irrigated. The total irrigation water needs of the area was estimated to be about $1.705 .675 \mathrm{~m}^{3}, 274.442$ $\mathrm{m} 3$ for Palea Fokea and $1.431 .233 \mathrm{~m}^{3}$ for Anavisos (Saronikos Municipality, Agricultural Department).

The re-use of the wastewater, after treatment, is being proposed as a solution to the problem of the water resources of the area. The wastewater is proposed to be used for the irrigation needs during the summer and for the artificial recharge of the aquifers, under control. According to a study on a new wastewater treatment in Saronikos municipality, the total annual production of wastewater is expected to be about $2.599 .200 \mathrm{~m}^{3}$. A part of it, $1.705 .675 \mathrm{~m}^{3}$, could be disposed to cover the irrigation needs and the rest $893.525 \mathrm{~m}^{3}$ to the artificial recharge of the aquifers. Taking into consideration the minimum water necessities per cultivation for Attica water status according to C.Y.A. F 16/6631/89, the total water necessities were estimated for Palea Fokea and Anavisos and are presented in the following Table 3. The minimum water necessities per cultivation were calculated after summing the minimum water needs per cultivation category according to its factor plant, for the months from April to September when irrigation is necessary.

\section{Conclusions-Discussion}

The area is characterized from the increasing water demands and the overexploitation of the aquifers by over pumping. Due to the fact that the phenomenon of degradation of groundwater quality is extended all over the area, the water is improper for different uses in most of the cases. Additionally, the lack of natural recharge compounded the hydrological conditions, because of the small rainfall in the area. The overexploitation of the coastal aquifers, especially during the drought period, has caused the sea intrusion and thus the salinization of the aquifers even to the inland. During 2011, the phenomenon of salinization seems to be more expanded from the coastline than it is appeared to be during 2001. Moreover, the intense farming and overuse of fertilizers have caused an intense nitrate pollution of groundwater.

Some proposals regarding the rational water management are presented below:

$>$ Restricting over-pumping in order to cover irrigation needs that will help to reduce the salinization in the coastline from Palea Fokea to Anavisos.

$>$ The mountainous aquifers of Olympos, Keratovouni and Merenta should be investigated in order to exploit them, which have available water deposit of good quality.

$>$ A number of constructions could take place in specific areas, such as flood control and anti-corrosion constructions that will also contribute to the artificial recharge of the aquifers and thus will increase the groundwater volume and improve its quality.

$>$ Rehabilitation of dumps and quarries is proposed in order to avoid water pollution.

$>$ Improvement of the sewer system in order to stop leaking, which pollute groundwater.

$>$ Establishment of a wastewater treatment specified to permit the reuse of wastewater in order to cover irrigation or other needs (except for that of drinkable water).

$>$ The existing of numerous absorbable wells and the lack of wastewater treatment.

$>$ Local governance should focus on sustainable management of local water resources.

The re-use of the wastewater, after treatment, is being proposed as a solution to the problem of the water resources of the area. The wastewater is proposed to be used for the irrigation needs during the summer and for the artificial recharge of the aquifers, under control. According to a study on a new wastewater treatment in Saronikos municipality, the total annual production of wastewater is expected to be about $2.599 .200 \mathrm{~m}^{3}$. A part of it, $1.705 .675 \mathrm{~m}^{3}$, could be disposed to cover the irrigation needs and the rest of it about $893.525 \mathrm{~m} 3$, could be used to the artificial recharge of the aquifers.

XLVII. No 2-689 
Table 3 - Cultivations and irrigation water needs of Palea Fokea and Anavisos.

\begin{tabular}{|c|c|c|c|}
\hline \multicolumn{4}{|c|}{ Irrigated cultivations of Palea Fokea Municipality (2010) } \\
\hline Cultivation & $\begin{array}{c}\text { Minimum Water } \\
\text { necessities } \\
\left(\mathrm{m}^{3} / \mathrm{m}^{2} / \text { year }\right)\end{array}$ & $\begin{array}{l}\text { Area } \\
\left(\mathbf{m}^{2}\right)\end{array}$ & $\begin{array}{c}\text { Water } \\
\begin{array}{c}\text { Consumption per } \\
\text { year }\left(\mathrm{m}^{3}\right)\end{array} \\
\end{array}$ \\
\hline $\begin{array}{l}\text { Tomatoes, beans, zucchini, okra, } \\
\text { eggplant, Other Horticulture }\end{array}$ & 0,67 & 201.000 & 134067 \\
\hline Peanut trees & 0,62 & 150.000 & 93150 \\
\hline Almond, & 0,62 & 35.000 & 21735 \\
\hline Citrus & 0,52 & 35.000 & 18340 \\
\hline Urban green (mainly grass) & 0,72 & 10.000 & 7150 \\
\hline SUMMARY & & & 274.442 \\
\hline \multicolumn{4}{|c|}{ Irrigated cultivations of Anavisos Municipality (2010) } \\
\hline Vegetables & 0,67 & 8.000 & 5336 \\
\hline Cauliflower & 0,67 & 2.000 & 1334 \\
\hline Spinach & 0,67 & 6.000 & 4002 \\
\hline Leeks & 0,67 & 2.000 & 1334 \\
\hline Onion & 0,67 & 20.000 & 13340 \\
\hline Celery & 0,67 & 1.000 & 667 \\
\hline Radish & 0,67 & 2.000 & 1334 \\
\hline Peas & 0,67 & 60.000 & 40020 \\
\hline Beans & 0,67 & 30.000 & 20010 \\
\hline Lettuce & 0,67 & 10.000 & 6670 \\
\hline Chicory & 0,67 & 2.000 & 1334 \\
\hline Tomatoes & 0,67 & 30.000 & 20010 \\
\hline Green beans & 0,67 & 8.000 & 5336 \\
\hline Okra & 0,67 & 1.000 & 667 \\
\hline Zucchini & 0,67 & 5.000 & 3335 \\
\hline Cucumbers & 0,67 & 2.000 & 1334 \\
\hline Eggplants & 0,67 & 2.000 & 1334 \\
\hline Peppers & 0,67 & 3.000 & 2001 \\
\hline Artichokes & 0,67 & 1.000 & 667 \\
\hline Olives trees & 0,52 & 1200.000 & 628800 \\
\hline Peanut trees & 0,62 & 250.000 & 155250 \\
\hline Citrus trees & 0,52 & 900.000 & 471600 \\
\hline Pear trees & 0,62 & 33.000 & 20493 \\
\hline Urban green (mainly grass) & 0,72 & 35.000 & 25025 \\
\hline SUMMARY & & & 1.431 .233 \\
\hline TOTAL SUMMARY & & & 1.705 .675 \\
\hline
\end{tabular}

As a general remark, the re-use of the wastewater would be the solution not only to create new water deposits in the area, but also to improve the quality of water resources. Wastewater can be used for the sustainable management of the area's water resources. Groundwater's over-pumping from drills and wells could be restricted if wastewaters cover the increased irrigation needs during the summer. Also the treated wastewaters could be used for artificial recharge of the aquifers, considering that, they will be of good quality and to continues monitoring. 


\section{References}

Angelakopoulou P. 2011. Water Resources status of the Anavisos basin with emphasis to groundwater, postgraduate study DPMS 'Water Resources Science and Technology', National Technical University of Athens, Athens 2011

C.Y.A. F 16/6631/89. Determination of minimum and maximum irrigation water necessities for the sustainable use of irrigation water.

Helenic National Meteorological Service, Meterological data from the stations Elliniko (time period 1955-2004), Markopoulo (time period 1971-2009) and Spata (time period 1974-2004).

Kallergis G. 1986. Applied Hydrogeology, Volume A, T.E.E. Athens 1986

Koumantakis I. etc. 1986. Plain of Anavisos and Palaia Fokaia, Research Project in National Technical University of Athens, Athens 1986

Koumantakis I. Groundwater quality, Course Notes 'Advanced Hydrogeology', DPMS 'Water Resources Science and Technology', National Technical University of Athens

Koumantakis I. Saronikos Municipality Water Resources, Course Notes Course Notes 'Advanced Hydrogeology', DPMS 'Water Resources Science and Technology', National Technical University of Athens

Kounis G. 1998. Hydrogeological study of Attica. Athens, IGME

Misopolinos N. 1991. Problematic Soils Study, Prevention, Improvement, Editions Giahoudi Giapouli, Thesaloniki

Mposinakou P. 2002. Hydrogeological study of the area of the Anavisos basin, postgraduate study DPMS 'Water Resources Science and Technology', National Technical University of Athens, Athens 2002

Pavlopoulos K. 1997. GAIA No 2: Geomorphological Evolution of South Attica', E.K.P.A.: Geology Department

Saronikos Municipality, Agricultural Department, Cultivations in Anavisos and Palaia Fokea for the year 2010

Tsakiris G. 2004. Water Resources-Irrigation water quality, postgraduate study DPMS 'Water Resources Science and Technology', National Technical University of Athens, Athens 2011 